\title{
Challenges, competences, professions for the built heritage conservation in the contemporary world Stefano Francesco MUSSO
}

\begin{abstract}
Starting from two famous sentences about the relationships between ruins and history and about the meaning of tradition, the article deals with many facets that conservation has in the contemporary world. Through an initial provocative example of recent re-production of a monument, some of the new challenges in - and for - conservation emerge in relation with the consolidate goals of the discipline of restoration. New problems, issues and contradictions are now on the fore in cultural heritage safeguarding, management and enhancement, but also some new possibilities for education and professional activity characterize the field.
\end{abstract}

Key words: Conservation, Restoration, Cultural Heritage, Competences.

\section{An initial tale}

This article has the same title and reflects the contents of the conference organized in Chisinau in June 2018 within the framework of the twin programme between Italy and Moldova on Cultural Heritage. It also widens the contents of the contribution presented to the RIPAM international conference in $2017^{1}$.

In both occasions, I started my reflection quoting two sentences that I consider very interesting for those who work in the field of conservation of cultural and especially built heritage.

The first statement is from the book Ruins written by the French sociologist Marc Augér and it helps in understanding the complex relationships existing between ruins and History. Augér states that: "History in the future will not create anymore ruins but only rubbles. It will not have time enough..." ${ }^{2}$. This simple but very strong sentence suggests a good reason for the protection of the ruins as remains of ancient civilizations. That statement nevertheless invites us

1 MiBACT-Ministero dei beni e delle attività culturali e del turismo - Ministerul Educației, Culturii și Cercetării - Project "Support to promote cultural heritage in the Republic of Moldova through its preservation and protection" - Open Conference - Chisinau - Moldova - 14 June 2018 - Stefano F. Musso, Les nouvelles „Instances de protection, de conservation et d'évaluation - in D. Pittaluga, F. Frattini (ed), Conservation and promotion of architectural and landscape heritage of the Mediterranean coastal sites. Abstracts of RIPAM 7- Rencontre Internationale sur le Patrimoine Architectural Méditerranéen - 2017 Conference, Genoa, September 20th - 22nd 2017 - Franco Angeli, Milano 2017.

2 Marc Augé, Rovine e macerie. Il senso del tempo, Bollati Boringhieri, Torino 2004, pp. 75-76 (tit. orig., Le temps en ruine, Edition Galilée, Paris 2003). 
to a more expanded protection of existing buildings and sites that we consider important for our culture from many points of view and different reasons. We have in fact to prevent the risk that they simply disappear in the future, reduced not in ruins but in mere rubbles, rubbish or wastages without any memory, value and meaning.

The other statement is by Gustav Mahler, at least according to some scholars. Mahler was a famous musician and a composer, protagonist of the profound renovation of the classic and symphonic music between the nineteenth and the twentieth centuries. He was in fact convinced that the tradition "is not about to contemplate and adore the ashes, but to keep alive the fire". We cannot in fact be slaves or passive followers of the past, because a true and alive tradition always implies a pro-active attitude towards the future that in any case will arrive.

The two statements, in my opinion, can help us in facing the new challenges that the contemporary, globalized and quickly changing world poses for the protection, conservation/restoration, enhancement or valorisation of our Cultural Heritage. By quoting those sentences, we can in fact start our common reflection without re-proposing, in ritual or liturgical ways, the same arguments that are common among ourselves (supposed experts), but that are often incomprehensible for the wider public involved in the issues of the destiny of our cultural heritage.

In the same informal and somehow heretical spirit, I used during the conferences a provocative picture apparently referable to the interior of the Sistine Chapel in Vatican City, with the famous frescoes by Michelangelo Buonarroti

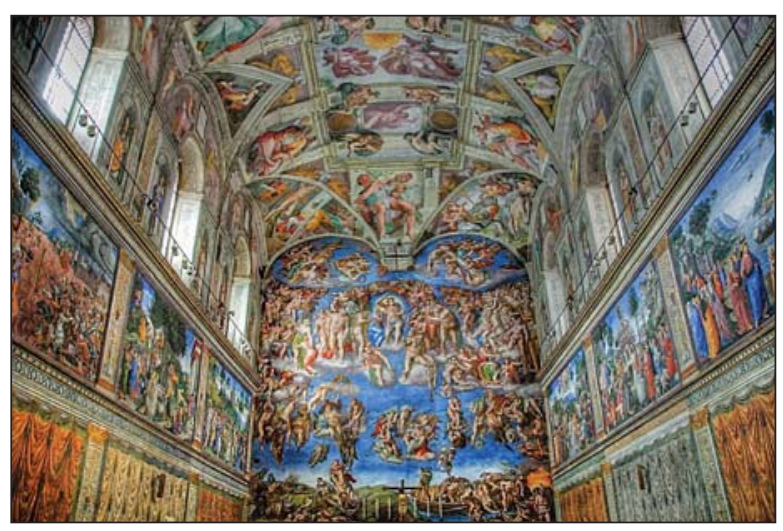

Fig. 1. Replica of Sistine Chapel in Mexico City and others great painters (Fig. 1). That place is a real shrine of the Italian Renaissance, well-known all over the world. "If" that image really portrays the Sistine Chapel and if we imagine to go out that space and to climb up on Saint Peter's dome, we would have the view of the exteriors of the Chapel (Fig. 2). Continuing this hypothetical journey, let us go back inside the chapel portrayed in the first picture and, immediately after that, let us exit again from it. At this point, our virtual trip ends up with a real surprise because the third picture (Fig. 3) records 
what we would exactly see. It is not at all the exterior of the real Sistine Chapel (Fig. $3)^{3}$ as everyone can see, because it shows a provisional structure made of metal scaffolds with black curtains closing its volume.

The third image, in fact, documents the perfect copy (clone, replica, and reproduction) of the interiors of the real Sistine Chapel in Rome that Gabriel and Antonio Berumen, movie directors and producers recently realized in Mexico City aside the Monument of the Revolution ${ }^{4}$. This provisional and astonishing structure has been possible thanks to millions of pictures reproducing the Sistine

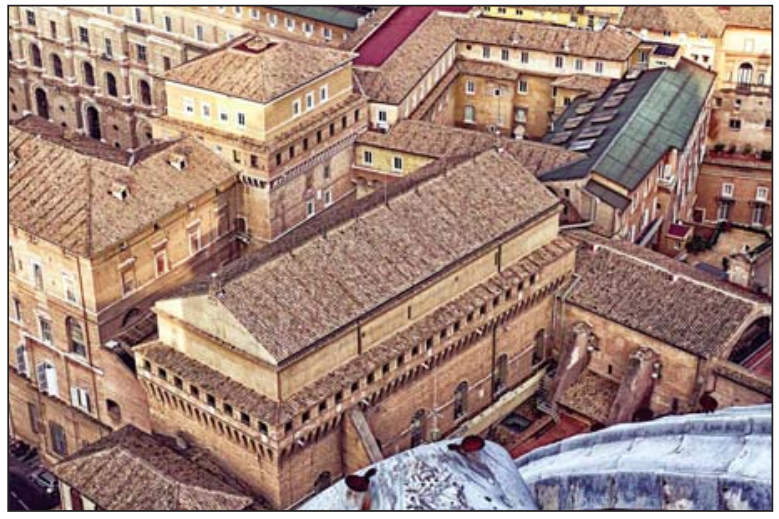

Fig. 2. Sistine Chapel exterior

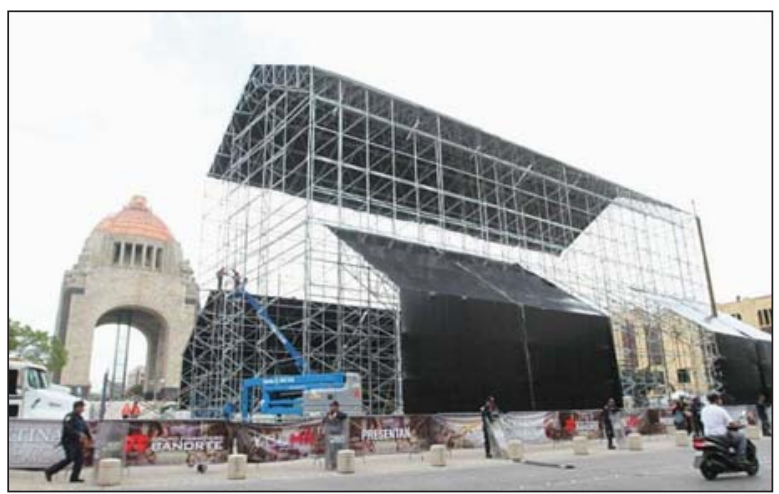

Fig. 3. Replica of Sistine Chapel in Mexico City (exterior)

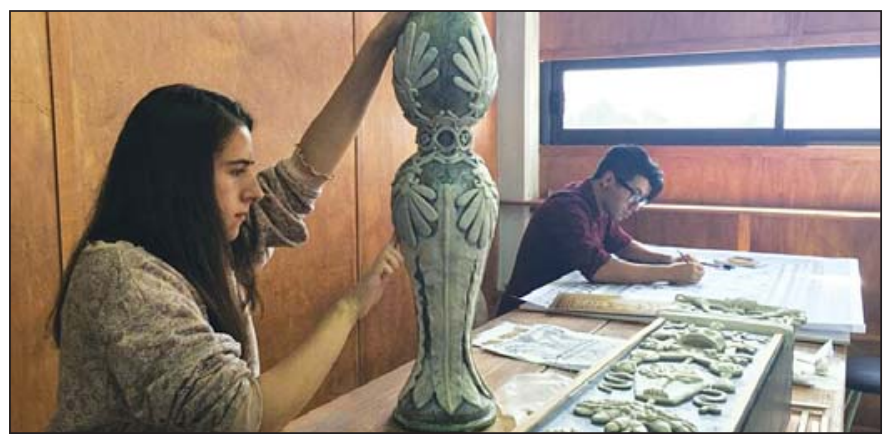

Fig. 4. Replica of Sistine Chapel in Mexico City (replica of furnitures)

Chapel's frescoes at the highest possible resolution and to the faithful copies of all the other furniture and architectural elements of the real chapel (Fig. 4).

The most interesting fact is that it is a multi-sensorial 'replica', with all the smells, flavours, sounds and lights that everyone can experiment during the visit to the "true" Sistine Chapel in Rome

3 The image 2 is from the web site: https://www.easyviaggio.com/vaticano/la-cappella-sistina

4 The images 1 and 3 are from the web site: http://www.repubblica.it/esteri/2016/08/05/ foto/messico_cappella_sistina-145397848/1/\#1 
(original, authentic, unique and irreplaceable). The replica is $22 \mathrm{~m} . \mathrm{x} 67 \mathrm{~m} . \mathrm{x} 22$ $\mathrm{m}$, occupying a total of $510 \mathrm{~m}^{2}$ - the dimensions of the "original" that remember those of the Jerusalem's Temple, according to the tradition. This installation thus shows the incredible and everyday improving capacity to create very faithful copies of ancient artefacts. This inevitably brings our attention to the fundamental and somehow incredibly prophetical book published by Walter Benjamin in the 30s of the last century, not for sure imagining this kind of development: "The work of art in the age of its technical reproducibility". 5

\section{Consequences of re-production}

In the difficult confrontation and debate about original/authentic/fake, this case is not very problematic at the end. No confusion or misunderstanding are in fact possible in this case: everyone entering the provisional structure is aware of being in Mexico City, very far from Rome, and that what they are going to live/experiment is something completely different from being in the real Sistine Chapel. One could also argue that this is a very good and effective method to widen the awareness and appreciation of the world's Cultural Heritage. That provisional installation - many countries already asked to host it in the future offers to a multitude of people, who will never have the chance to go to Rome, a possibility to see and discover this masterpiece of art, even if in a delayed or differed, displaced and virtual way. This partial copy-replica can in a certain way offer to many an immersive journey inside it - concrete but also somehow virtual - remaining very well aware of this "unreal" condition. The construction of this "installation" furthermore implied a deep knowledge of the original, many

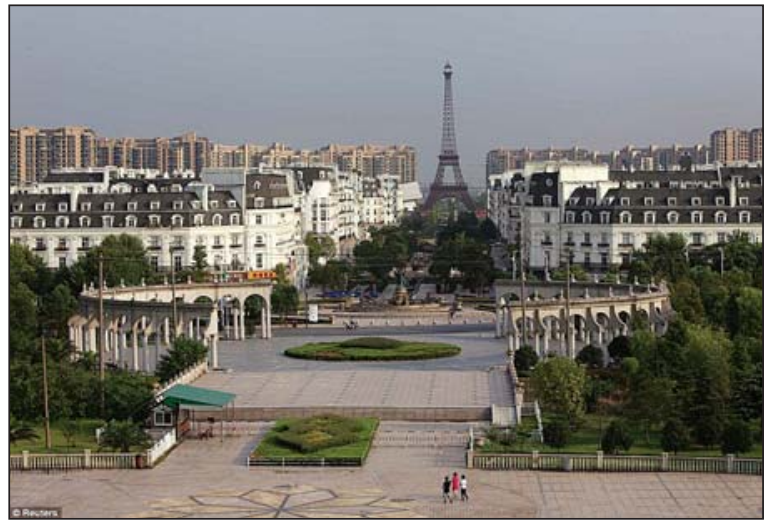

Fig. 5. Replica of Eiffel Tower, China competences, skills and the work of several experts and artisans in many fields. All these aspects are in a way very important for the life and the future of our Cultural Heritage. As a provisional conclusion, we could thus say that no problem exists with this particular replica or copy if we are aware of its nature and scope. We can-

\footnotetext{
5 Walter Benjamin, Das Kunstwerk im Zeitalter seiner technischen Reproduzierbarkeit, in: Zeitschrift für Sozialforschung, 1936 (translation by the author).
} 
not confuse it with the real Sistine Chapel, in any way and for any purpose. Unfortunately, in many other cases all over the wold this incredible capacity of faithful and convincing - or confusing - re-production can create real "disasters" and deep confusion in the eyes and the minds of people. What one could in fact really understand about their cultural values when meeting, for example, a copy of the Eiffel Tower in China (Fig. 5) ${ }^{6}$, a "new Coliseum" in Thailand (Fig. 6) 7 , or a collection of replicas of simple fragments from many world's monuments in Dubai (Fig. 7) ${ }^{8}$ ?.

Facing these "extreme" examples, in fact, we have

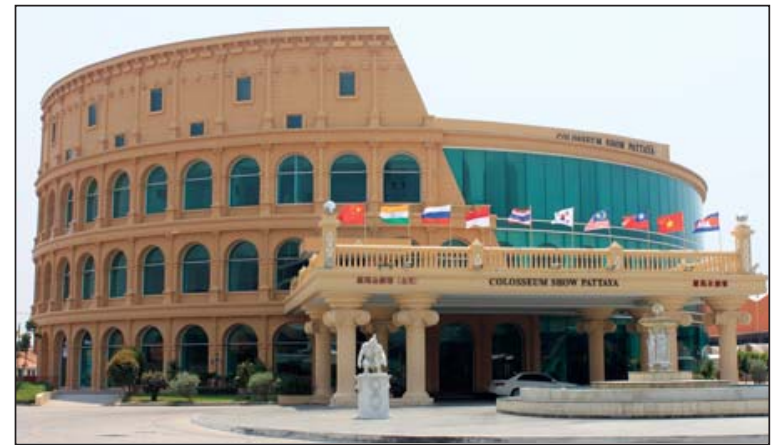

Fig. 6. Replica of Coliseum, Thailand

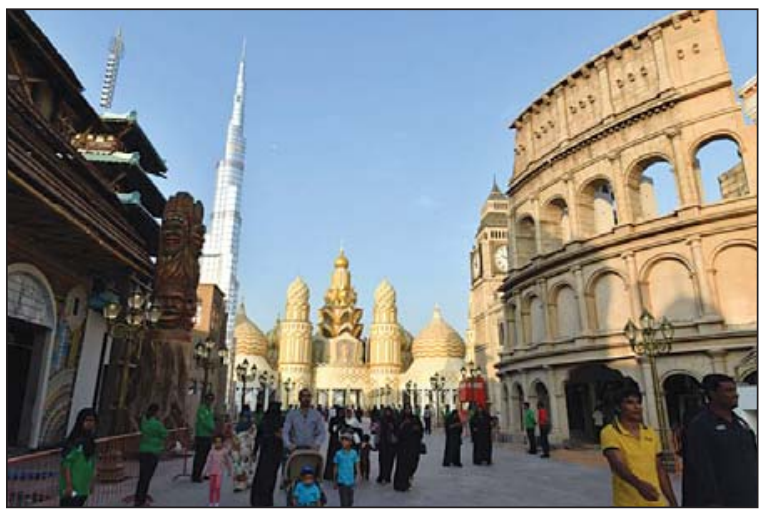

Fig. 7. Replicas of world's monuments in Dubai to interrogate ourselves about what we can still say about the concepts/ ideas of "material-immaterial", or "tangible-intangible" heritage, as well as about terms like authenticity, integrity, originality, identity/roots or even about reversibility, compatibility, change management, tradition, innovation, minimum intervention and other similar ones. We usually consider these words-concepts-requirements as universally accepted and clear. However, the above-mentioned examples show that perhaps it is not exactly like this and we should thus interrogate again ourselves about the real meanings of these words/concepts in front of some astonishing cases of physical partial or total

${ }^{6}$ We refer to the copy of the Eiffel Tower in the Tianducheng development, Hangzhou, Zhejiang Province - See: http://www.technocrazed.com/chinese-replica-of-city-of-paris-withits-eiffel-tower-photo-gallery

7 The image 6 is from: https://www.coastalrealestatepattaya.com/en-gb/articles/2016/3/7/ part2-do-you-live-in-pattaya

8 The images 7 is from: https://gulfnews.com/multimedia/framed/leisure/big-ben-coloseotaj-mahal-replicas-at-dubai-s-global-village-1.1612673: 
re-construction/re-productions of ancient monuments of different kind, history, nature, consistency and place.

In front of these unexpected phenomena, also a crucial question of more general nature inevitably arises. We must in fact ask ourselves if we are ready to inherit what we call Cultural Heritage (or Inheritance or Legacy). Are we able, in other words, to realy take care of this impressive mine of knowledge, specificities and of cultural richness? We must in fact carefully consider as a crucial value the uniqueness of what we define cultural heritage, overpassing the illusion that what can be technically faithfully re-produced can substitute it. We must critically consider that this possibility does not at all make now less important - or even unnecessary - the protection of what we identify as /assets/ sites of Cultural Heritage in their present material consistency and status, rich of all the traces that History left upon and inside them.

\section{Why to conserve/restore Cultural Heritage nowadays}

After two centuries of cultural debates, disciplinary confrontations and of real interventions on pre-existing artefacts that we identify as parts of Cultural Heritage, we need perhaps to ask again what this expression really means and, as a consequence, which are the meanings of (and spaces for) conservation, restoration, valorisation and so on. Facing the recurrent opposition between the extreme polarities of the pure (but never possible) conservation and the (sometime profoundly inventive) restoration, we have once again to take a position. Following the processes of progressive expansion of our cultural heritage(s) for kind, age of formation, quantity and quality - we must clarify what we really intend with these terms. We have to look towards wider horizons of meanings, working perhaps to obtain new results in this complex and unexhausted field of human sensitivity-creativity, of intellectual and doctrinal elaboration and of pragmatic actions-interventions.

We perfectly remember and exactly know what happened in the recent past and we can at least recall, in extreme synthesis, some passages of this process. Alois Riegl, in his book "The modern cult of ancient monuments", already in 1903, analysed what he qualified as a sort of "religious attitude" that his age for the first time in History expressed towards the material traces of previous centuries still surviving in his world. The nineteenth century's ideas of the Monument as a "Glory for the Country", a witness of the past has been overpassed by the later concept of "Patrimoine"10 - not exactly corresponding to Herit-

9 Tit. or. Alois Riegl, Der moderne Denkmalkultus. Sein Wesen und seine Entstehung, Wien-Leipzig, 1903.

${ }^{10}$ Françoise Choay, L’Allégorie du patrimoine, Paris, Éd. du Seuil, 1992. 
age - and continuously changing in times and space, according to Francoises Choay. Furthermore, new values and requirements are now on the fore in this field (social benefits and cohesion, well-being, community engagement, universal accessibility, sustainability and so on). We thus consider very important and valuable not only some single masterpiece of art, as isolated and unique objects with outstanding aesthetical and/or historical values. We perfectly know, at this point of the long historical, ideal and practical processes that brought to the present situation that a monument or a site, considered as cultural goods, have also outstanding social and economic values. We are also aware that we have now to deal with complex and wider systems of cultural goods and to look at entire built cultural landscapes more than, or aside, their single and separate elements.

We are also aware that Cultural Heritage is made of material traces among which are buildings/sites/structures and infrastructures - still used, partly or completely abandoned - remains, relics of different origins, age and consistency. Through these material traces of the several pasts that preceded the present times also many immaterial (intangible) memories, meanings and values (emotions, stories, knowledge, abilities...), that belonged to our ancestors, still survive embedded and sometimes hidden in their material bodies. The cultural goods on the other hand do not certainly belong to the past. Past is not anymore here, it will never come back as it was and we will never know how it really was in its wholeness. Those goods belong to our present and should arrive to the future generations as much "intact" as possible, enriched by new "layers" (formal, material, of meanings) instead of deprived of the existing ones. They can in fact improve the quality of the environment and of our life and they could do the same for our descendants, if we consciously and rigorously take care of them.

Unfortunately, it is sometimes very difficult to explain to individuals and local communities why an old or ancient artefact is important and we should protect, conserve or restore it for the general good of the entire society, today and in the future. It is also difficult to consider the contradictions that any intervention on a good/asset of cultural interest and value brings with itself as the consequence of different theories, methods, attitudes that characterized the past two centuries and still sign this field.

Very often, people do not know and appreciate those objects/artefacts and do not understand why we should spend time and money to save instead of simply demolishing and substituting them with new and more efficient, safe, polite, clean or beautiful buildings, or even leaving their space empty and available for new purposes and uses. It is difficult to explain and motivate why we (supposed experts) consider those things important, but let us for a moment change 


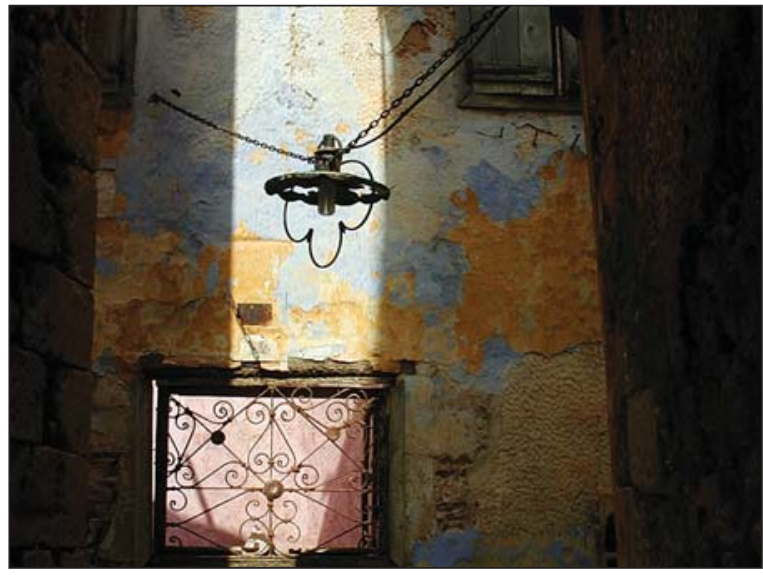

Fig. 8. A ruined wall. Chania (Greece)

the perspective leaving that someone else, not involved in conservation, suggest another way for looking at those poor or apparently banal and ruined things (Fig. 8).

In an interesting essay dedicated to some "visionary artists", the French philosopher and art critic Henry Focillon dedicates some pages to Leonardo da Vinci. He notices that "looking at a piece of ruined wall, destroyed by many winters, dirty because of dump, engraved by plants and biological agents, Leonardo follows the enigmatic path of the fissures, like it were the sign of a drawing and so he discovers in these traces marvellous forms and shapes [....]. This phenomenon is not pure: there is observation, reconstruction, but also [.... there is evocation and images matched together". ${ }^{11}$

This passage suggests that, perhaps, in order to overpass the highlighted problems of communication/explanation we should look through different eyes and mind at what everyone looks at, but that probably does not really see and understand. This is exactly what Leonardo did thus discovering what anybody else saw in that same fragment of an ancient and ruined wall. On the other hand, Wolfgang Goethe wrote in his Journey in Italy that "it is not true that we know what we see. Rather, we only see what we already know". We could add that if we know (and understand) what we are in front of, perhaps we will then love and respect it. We also should never forget that we are only provisional heirs of the legacy that we now define Heritage, because those goods still partly belong to those who created them and should as well belong to those who will arrive after us (J. Ruskin, W. Morris). Those artefacts should be therefore protected, preserved and conserved. For this aim, a constant care and a programmed conservationmaintenance are necessary, as it is possible a prudent restoration intervention looking for compatible new-uses for the existing buildings that lost their original ones. The problem is that sometimes these activities determine the production of strange and unnecessary simulacra (clones) of the lost appearance of the buildings/sites we are working on. In other cases, the interventions trans-form those artefacts in such a way that they are at the end really unrecognizable.

${ }^{11}$ Henri Focillon, Estetica dei visionari, Abscondita, Milano 2006, pp. 17-18 (translation by the author) - Fig. 8 is from the author. 
On the other hand, conservation has to do with all the matters and all the techniques of ideation and realization (traditional, innovative, ancient, modern) but it is not - and will never be - a simple or a mere technical problem. We cannot reduce conservation-restoration to any technical choice that of course we will anyway assume. The real meaning of our interventions can only derive from the project (design) that first regards the people and only afterwards the things and their destiny. For these reasons, we must explain, motivate and communicate any desire for conserving/restoring a material asset of cultural heritage to the involved local communities. Only in this way, that effort will be culturally sustainable (not only socially, economically or environmentally). Conservation and management of our Heritage(s) or "Inheritance(s)" will thus be - and felt - a chance rather than a mere, uncomfortable load or a difficult problem.

\section{Innovation in-for Conservation}

Innovation in itself is not an absolute positive value. Aims are not mediums and tools used to find an answer to a given conservation problem cannot be merely technical. It must be cultural, structured and not casual, in social, economic, scientific and technical terms. Here is where we really need innovations in mind-set more than on a simple practical level.

In any case, we need to innovate and develop our ideas and instruments in this complex, contradictory and conflicting field.

We still need to realize:

- rigorous architectural surveys, supported by adequate technological tools and devices and based on serious and controlled geometrical basis;

- serious historical inquiries, founded on indirect archive sources constantly compared with the archaeological analysis of the artefacts considered as the first and direct sources of their history;

- meticulous analytical and diagnostic non-destructive tests of empirical and/or of scientific nature (laboratory tests) on the materials employed in the artefacts and on their state of conservation;

- analysis and interpretation of the constructive techniques, also carried out through the history of the material culture;

- basic or sophisticated structural analysis, by using also specific interpretative numeric 3D models and non-destructive tests;

- refined and reliable virtual simulations of the designed interventions regarding the built materials and elements, the layout of the ancient buildings after the completion of the works on site;

We also need accurate models and methods for virtual analysis about: 
- the structural behaviour of ancient buildings and structures (facing the earthquakes' actions or other natural or humanly provoked disasters as fires, floods, landslides);

- the physical, energetic and functional behaviour of the ancient buildings within the environment never pretending they can match the requirements for new buildings, also regarding the indoor comfort.

\section{ICT and Conservation}

An important help can derive in this perspective from the computerized systems applied to surveying and cataloguing the cultural goods, if they are not self-centred and self-directed. We can take advantage of various databases for analytical, diagnostic and intervention phases of the conservation process, if they are not simple collections of meaningfulness data, form the GIS Systems or from a BIM adapted to the specificities of any cultural good/asset.

A challenging relationship nevertheless exists between the "Information Communication Technologies" and the disciplines that deal with the knowledge and the care of the material and immaterial depot of our cultural heritage. We should therefore always explain what kind of information we refer to and for which purposes of communication we intend to use those technologies. This also considering that the tools should never take the prevalence over the goals of our actions. Any effort and all the resources we use to exploit the capabilities of the modern ICT for broadening our knowledge, for the understanding, appreciation and enhancement of the heritage will be in fact unnecessary costs if, in the meantime, the goods that we want to preserve, will disappear. Every innovation will be thus welcome only if the "meta-data" do not eat or metabolize until disappearance of the data, which is the artefacts we are interested.

Thanks to the revolution of the digital era, whose potential impacts we still do not fully foresee, conservation opens towards unexpected development. We do no longer talk only of virtual reality but also of augmented reality. Someone imagined, for example, some virtual field trips to visit museums, monuments or archaeological sites, without having to move from where we are. The sense of time and of space thus deeply change, but they are always fundamental for any real comprehension of what we are dealing with. These are fascinating frontiers for the research, full of potential developments for humans, but they can also hide some risks. The new virtual or augmented realities should not take place at the expense of the uncertain factual reality of the heritage, in its perishable but unreplaceable materiality that we have to preserve. It is not a matter of contraposition and we have simply to decide and control the ways these tools are used and for which real purpose. 
New thus needs deeper links between ICT applied to Cultural Heritage and its physical conservation as well as between the ICT competences and those involved in the design and realization of the conservation interventions. A more effective integration between the two sides of the moon is also strongly advisable in terms of funding policies supporting ICT applied to Architectural Heritage and for the allocation of sufficient resources into the educational and training activities in this field.

For all these reasons, we need new competences, abilities and skills and this is an open field for future actions in the educational and training systems in each Country. New professionalisms are needed (analytical, diagnostic and design oriented) and any solution in this field cannot be the result of a simple and indistinct sum of separate answers and solutions. The training sector and the Universities should thus identify and create new competences, promote a new and stronger sensitivity for conservation as prudent management of the changes and stimulate a clear view of the many strategic aspects of the tutorship, in terms of structural and long-term governance of the system of goods we are interested in (and are responsible for). Conservation and restoration, in fact, can never look backwards because they do not work for the past but for the future and architects can play an important role in this adventure.

\section{New challenges for our Heritage}

Conservation-Restoration culture is not (or should not be) a withdrawn, self-sufficient or self-related world, separated from architecture. Architecture and conservation often look like poor neighbours, as Loughlin Kealy said, and do not communicate. They often suffer the contraposition between exaltation of pure (or abstract) creativity and the search for analytical rigour, that is also the tension between pure knowledge (never existing as such) and professional pragmatism. We rather need the profound integrations of both these universes. Furthermore, conservation and restoration belong to architecture because they share the same aim of inhabiting the world, taking care of it. In this perspective, it is of crucial importance to reach a balance between the conservation of the memories of the past (which can be still significant for our present) and a future that must be free but not oblivious, not to waste what Earth has given and still gives us.

Finally, at least a synthetic reference is necessary to some other new challenges that the present and quickly changing world poses to ourselves and to all those involved in the care of our cultural and built heritage.

We must in fact take into account the overwhelming processes of a distorted globalization that can provoke: 
- the sudden and progressive disappearance of local specificities and differences, within a destructive process of homogenization of cultural values and environments;

- the opposed but not less destructive research for the improvement or the creation of fake local identities, often due to exclusive political-ideological or commercial reasons.

We should neither forget other emerging and already quoted needs for:

- a true environmental, energetic, social and, even more, cultural sustainability of our interventions on the built Heritage and environments;

- a real universal accessibility - physical or mediated and first of all "cognitive" - of our monuments, landscapes and sites;

- the effective defence of our cultural heritage against the risks of fire, earthquakes, floods or of other natural or "provoked by men" disasters.

- the widest possible involvement of the local communities in the management of their heritage, as Faro Convention invokes.

We can thus conclude this short reflection saying that still there is space and need to work in this field, with open minds and hearts and with new competences and abilities that the education and training systems should ensure in each country to the youngest generations to better their own future.

\section{Rezumat}

Pornind de la două propoziții celebre despre relațiile dintre ruine și istorie și despre semnificația tradiției, articolul se ocupă de multe aspecte pe care conservarea le are în lumea contemporană. Printr-un exemplu provocator inițial de reproducere recentă a unui monument, unele dintre noile provocări în - și pentru - conservare apar în legătură cu obiectivele consolidate ale disciplinei restaurării. Astfel, studiul dezbate noile probleme, aspecte și contradicții actuale în domeniul protejării, gestionării și îmbunătățirii patrimoniului cultural, dar și unele noi posibilități de educație și de activitate profesională ce caracterizează domeniul.

Cuvinte-cheie: conservare, restaurare, patrimoniu cultural, competențe 